\title{
Evaluation of the Effect of EDTA, EGTA and CDTA on Dentin Adhesiveness and Microleakage with Different Root Canal Sealers
}

\author{
Manoel D. SOUSA-NETO ${ }^{1}$ \\ Jarbas Gonçalves PASSARINHO-NETO \\ Jacy Ribeiro CARVALHO-JÚNIOR ${ }^{1}$ \\ Antonio M. CRUZ-FILHO ${ }^{1}$ \\ Jesus D. PÉCORA ${ }^{2}$ \\ Paulo César SAQUY ${ }^{1,2}$ \\ ${ }^{1}$ Faculty of Dentistry, University of Ribeirão Preto (UNAERP), Ribeirão Preto, SP, Brazil \\ ${ }^{2}$ Department of Restorative Dentistry, Faculty of Dentistry, University of São Paulo, Ribeirão Preto, SP, Brazil
}

\begin{abstract}
The effect of chelating solutions EDTA, EGTA and CDTA on human dentin adhesiveness and microleakage with 4 sealers (Sealer 26, Sealapex, N-Rickert and Endofill) was evaluated in vitro. Whether or not there was a mathematical correlation between the tests of adhesiveness and microleakage was also evaluated. A total of eighty maxillary and mandibular molars were used to test adhesiveness. After wearing of the occlusal surface to obtain a flat surface, the sealer was placed with an aluminum cylinder (10 $\mathrm{mm} \times 6 \mathrm{~mm})$. Adhesiveness was evaluated with a 4444 Instron universal testing machine. Microleakage was evaluated in 160 maxillary canines after root canal instrumentation, obturation and clearing. The penetration of India ink in the apical region was measured with a measurescope. The teeth were divided into 4 groups: group 1, distilled water; group 2, EDTA; group 3, EGTA; group 4, CDTA. Sealer 26 and EDTA had the best results $(p<0.01)$ for adhesiveness and microleakage. There was no correlation between the test for adhesiveness and microleakage.
\end{abstract}

Key Words: endodontics, physico-chemical properties, root canal sealers.

\section{INTRODUCTION}

In order to achieve success in endodontic therapy, all steps of treatment must be followed carefully and a hermetically sealed root canal is necessary. Cohen and Burns (1) state that obturating a root canal means filling in all its extension with an inert and anti-septic material, thus sealing that space. Obturation must not interfere with and, if possible, should stimulate periapical tissue healing, which must occur after endodontic treatment.

Specification number 57 for endodontic obturating materials of the American Dental Association does not recommend a model for adhesiveness and apical microleakage tests. Adhesion of a root canal sealer means its capacity to attach to the dentinal walls of the root canal and provide bonding between it and guttapercha points. Apical microleakage analysis means the capacity to evaluate qualitatively and quantitatively the penetration of fluids into the root canal system.

Kouvas et al. (2) and Kennedy et al. (3) reported that smear layer is a negative factor in root canal sealing, because this organic and inorganic material adheres easily to the sealing material and root canal wall interface reducing the adhesion of sealers. Thus, it is easy to understand the concern of researchers in relation to the removal of smear layer prior to root canal filling with the objective of penetration of the sealer into the dentinal canaliculi, causing the mechanical interlock and increasing the physical link of the sealer to the canal wall. In endodontic therapy, EDTA (ethylenediaminetetraacetic acid) has been used for this purpose (4).

There is much medical research about chelating solutions to detoxify heavy metals that contaminate 
patients. EGTA (ethylene glycol-bis-(beta-amino-ethyl ether) N,N,N',N'-tetraacetic acid) has been used by various researchers at low concentrations $(100 \mu \mathrm{M}-1$ $\mathrm{mM}$ ) when a medium free of calcium ions is needed (5). Sanchez et al. (6) reported that CDTA (cyclohexane1,2-diaminetetraacetic acid) reduced ion concentration significantly. Thus, considering that in the medical field many chelating solutions besides EDTA have been used and that there are specific chelating agents for calcium in neutral $\mathrm{pH}$, these solutions should be tested for use in endodontics. The aim of this study was to evaluate the effect of EDTA, EGTA and CDTA, applied to human dentin in vitro, on the adhesion of Endofill, Sealapex, N-Rickert and Sealer 26 root canal sealers.

\section{MATERIAL AND METHODS}

Four root canal sealers were used in this study: Sealer $26^{\circledR}$ (Dentsply; Rio de Janeiro, RJ, Brazil), NRicket $^{\circledR}$ (Inodon; Rio Grande do Sul, RS, Brazil), Sealapex ${ }^{\circledR}$ (Kerr Corporation; MI, USA) and Endofill ${ }^{\circledR}$ (Dentsply; Rio de Janeiro, RJ, Brazil). Sealer 26 is composed of powder and resin, Sealapex is paste based and the other two sealers are composed of powder and liquid. Powder/liquid, powder/resin ratios and setting times of each sealer were determined by the method proposed by Sousa-Neto et al. (7) (Table 1).

\section{Adhesion Test}

For the adhesion test, 80 extracted human maxillary and mandibular molars with intact crowns were kept in $0.1 \%$ thymol at $9^{\circ} \mathrm{C}$ until use. The crowns were cut on the occlusal side with $1212 \mathrm{KG}$-Sorensen diamond burs (KG-Sorensen; Baruiri, SP, Brazil) until a flat dentin surface was obtained. The teeth were fixed

Table 1. Values of powder/liquid, powder/resin, and setting time obtained in 5 repetitions for each sealer.

\begin{tabular}{lcccc}
\hline Sealer & $\begin{array}{c}\text { Grams powder/0.20 ml } \\
\text { liquid (range) }\end{array}$ & Mean (g) & $\begin{array}{c}\text { Setting time } \\
(\mathrm{min} ; \text { range })\end{array}$ & Mean (min) \\
\hline Sealapex & & & & 61 \\
N-Rickert & $0.78-0.90$ & 0.85 & $13-16$ & 15 \\
Endofill & $0.94-0.98$ & 0.95 & $30-35$ & 32 \\
Sealer 26 & $0.22-0.30$ & 0.26 & $1090-1482$ & 1125 \\
\hline
\end{tabular}

by their roots in a resin block and divided into 4 groups: group 1, distilled water; group 2, EDTA; group 3, EGTA; group 4, CDTA. Five repetitions were done for each group. The surfaces were washed for $1 \mathrm{~min}$ with running distilled and deionized water and air dried.

Aluminum cylinders $(10 \mathrm{~mm}$ in height and $6 \mathrm{~mm}$ in diameter) were manufactured. These cylinders, which had stainless steel lateral handles to which the tensile load was applied, were fixed laterally with utility wax on the prepared dentin. The sealers were mixed based on previously established powder/liquid or powder/ resin ratios (Table 1) and the cylinders were filled. The sample was placed in a sterilizer at $37^{\circ} \mathrm{C}$ with $95 \%$ relative humidity for a time that was three times the setting time of the material (Table 1).

This sample was then placed in an Instron 4444 universal testing machine (Instron Corporation, Canton, MA, USA) equipped with load cell, an oscillating system and a spring adapter. The machine was calibrated at a constant speed of $1 \mathrm{~mm} / \mathrm{min}$. The tensile load, in Mega-Pascal (MPa), required to cause failure of the bond was recorded.

\section{Apical Microleakage Test}

A total of 160 maxillary canines from laboratory stock kept in $1 \%$ thymol solution under refrigeration until use were used for the apical microleakage test. Standard access surgery was performed in all teeth, the pulps were extirpated and the pulp chambers irrigated copiously with $1 \%$ sodium hypochlorite. Length determination was performed with a \#15 K-file, one millimeter short of the anatomical apex, where the apical stop was prepared. The crown-down technique was used, and the master apical file was a \#50 K-file.

After root canal preparation, teeth were divided into four groups. Group 1 was irrigated with distilled water. Group 2 received $2.0 \mathrm{ml}$ of sodium hypochlorite between files and 10 $\mathrm{ml}$ as a final flush. After this, $2.0 \mathrm{ml}$ of $15 \%$ EDTA was placed into the root canal for $5 \mathrm{~min}$, followed by $10 \mathrm{ml}$ of distilled and deionized water. Groups 3 and 4 received the same irrigation regimen, but the chelating solutions were $1.0 \%$ EGTA and 1\% CDTA, respectively. Teeth were then filled with one of the sealers using the lateral condensation 
technique. The pulp chamber was then cleaned and sealed with Cimpat ${ }^{\circledR}$ (L Spécialités-Septodont, SanintMaur-Dês-Fossés, France). Teeth were subsequently immersed in distilled and deionized water at $37^{\circ} \mathrm{C}$ for $48 \mathrm{~h}$ for sealer polymerization.

The outer surface of the tooth was impermeabilized with cyanacrylate, with the exception of $2 \mathrm{~mm}$ from the apex of the root, and immersed in India ink at $37^{\circ} \mathrm{C}$ for $96 \mathrm{~h}$, allowing it to penetrate through the apical portion.

Teeth were then washed in tap water for $1 \mathrm{~h}$ and dried. The cyanacrylate layer was removed from the tooth surface with a scalpel. The teeth were immersed in 5\% hydrochloric acid for decalcifying, and then washed under tap water for $4 \mathrm{~h}$. Dehydration of the teeth was performed with an ascending series of alcohol $(70,85,96$ and $100 \%)$ and were cleared in methylsalicylate. Dye penetration was measured at the apical level with a measurescope (Nikon, Japan) (Figure 1).

Data were analyzed using ANOVA. Results showed statistical differences $(p<0.01)$ between tested sealers, but no differences $(\mathrm{p}>0.05)$ between tested solutions. The Tukey test was then applied for the determination of which sealers were different among each other.

\section{RESULTS}

Adhesion and apical microleakage test results are shown in Tables 2 and 3, respectively.

For the test of adhesion, the Tukey test did not show any statistical differences between the means of Endofill, N-Rickert and Sealapex. However, Sealer 26 had the best values of adhesion and was statistically different from the other three sealers $(\mathrm{p}<0.01)$. EDTA was statistically better than CDTA and EGTA which presented intermediate values. The group treated with distilled water presented the lowest values for the adhesion test (Table 2).

The Tukey test showed that
Sealer 26 had the least microleakage and was statistically different from the other sealers. N-Rickert had intermediate values and Sealapex and Endofill were statistically equal with the greatest values of microleakage. The root canals treated with EDTA had the lowest values of microleakage, with EGTA and CDTA intermediate values and with distilled water the greatest microleakage (Table 3).

A correlation and regression test was used to evaluate if there was a mathematical correlation between adhesion and microleakage and there was no correlation found.

\section{DISCUSSION}

Adhesion to the root canal wall is one of the properties that a sealing material must have. The Ameri-

Table 2. Load necessary to separate sealers from dentin with EDTA, EGTA and CDTA.

\begin{tabular}{lcccc}
\hline Treatment & Sealapex & N-Rickert & Endofill & Sealer 26 \\
\hline Control & $0.0004-0.0084$ & $0.0032-0.0071$ & $0.0038-0.0062$ & $0.0045-0.0123$ \\
& $0.0033 \pm 0.0045$ & $0.0044 \pm 0.0016$ & $0.0046 \pm 0.0010$ & $0.0168 \pm 0.0032$ \\
EDTA & $0.0000-0.0048$ & $0.0024-0.0096$ & $0.0044-0.0068$ & $0.0306-0.0308$ \\
& $0.0027 \pm 0.0017$ & $0.0055 \pm 0.0031$ & $0.0055 \pm 0.0011$ & $0.0349 \pm 0.0029$ \\
EGTA & $0.0011-00044$ & $0.0024-0.0112$ & $0.0063-0.0066$ & $0.0043-0.0167$ \\
& $0.0026 \pm 0.0013$ & $0.0070 \pm 0.0033$ & $0.0057 \pm 0.0009$ & $0.0151 \pm 0.0009$ \\
CDTA & $0.0000-00057$ & $0.0026-0.0074$ & $0.0045-0.0068$ & $0.0134-0.0377$ \\
& $0.0017 \pm 0.0022$ & $0.0044 \pm 0.0019$ & $0.0056 \pm 0.0009$ & $0.0215 \pm 0.0032$ \\
\hline
\end{tabular}

Data are reported as range and mean $\pm \mathrm{SD}$ in Mega-Pascal (MPa).

Table 3. Values, in millimeters, of apical microleakage.

\begin{tabular}{lllll}
\hline Treatment & Sealapex & N-Rickert & Endofill & Sealer 26 \\
\hline \multirow{2}{*}{ Control } & $0.39-0.75$ & $0.25-0.70$ & $0.20-0.78$ & $0.25-0.44$ \\
& $0.57 \pm 0.12$ & $0.49 \pm 0.16$ & $0.44 \pm 0.22$ & $0.37 \pm 0.01$ \\
EDTA & $0.25-0.79$ & $0.00-0.68$ & $0.20-0.52$ & $0.00-0.29$ \\
& $0.48 \pm 0.22$ & $0.29 \pm 0.30$ & $0.35 \pm 0.12$ & $0.12 \pm 0.12$ \\
EGTA & $0.40-0.80$ & $0.00-0.66$ & $0.38-0.84$ & $0.00-0.25$ \\
& $0.65 \pm 0.45$ & $0.33 \pm 0.15$ & $0.54 \pm 0.23$ & $0.11 \pm 0.09$ \\
CDTA & $0.42-0.88$ & $0.00-0.75$ & $0.29-0.84$ & $0.00-0.34$ \\
& $0.64 \pm 0.17$ & $0.35 \pm 0.30$ & $0.54 \pm 0.21$ & $0.13 \pm 0.09$ \\
\hline
\end{tabular}

Data are reported as range and mean $\pm \mathrm{SD}$. 
can Dental Association did not standardize a method for the study of adhesion because there is a lack of agreement among researchers. Ørstavik (8) used a universal testing machine to measure adhesion of root canal sealers. This method was also followed by Hyde (9) and Sousa-Neto et al. (10), who confirmed the uniformity and reproducibility of this machine. The values of bond strength expressed in MPa are accepted universally which allows the comparison of results. It is important to note that an oscillating system was used between the load cell and the spring adapter in the present study to avoid the application of eccentric load to the sensitive part of the load cell, thus eliminating errors of measurement (10).

Many researchers have evaluated the apical seal of root canals. In the present study, clearing was used to evaluate apical microleakage because it is simple, easy, economic and allows a tridimensional view of the root canal (11).

When $\emptyset$ stby (12) proposed the use of ethylenediaminotetraacetic acid at $\mathrm{pH} 7.3$ for instrumentation of atresic root canals, the use of strong and concentrated acids was eliminated. This proposal was based on the research of Nikiforuk and Sreebny (13) about the action of EDTA on decalcification of bone structures and its physical-chemical properties.

Much research has since associated EDTA with cationic or anionic surfactants which reduce superficial tension, easing the wetting of the dentinal walls (14). However, in Medicine, more specific chelating agents such as CDTA and EGTA are being used $(5,15)$. Sanchez et al. (6) researched the efficacy of EGTA and CDTA on the chelation of manganese in mice, and concluded that only CDTA reduced the ion concentration significantly. Recently, Johnson et al. (15) used EGTA to obtain an extracellular environment totally free of calcium.

In the present study, EDTA solution was statistically superior in adhesion tests compared to CDTA and EGTA, which presented intermediate values. The group treated with distilled water presented the lowest values for the adhesion test. There is a molar concentration difference between the chelating solutions (15\% EDTA $=0.419 \mathrm{~mol} / \mathrm{l} ; 1 \% \mathrm{CDTA}=0.0274 \mathrm{~mol} / \mathrm{l} ; 1 \% \mathrm{EGTA}=$ $0.0263 \mathrm{~mol} / \mathrm{l}$ ) that suggests a less efficient action of $1 \%$ CDTA and 1\% EGTA compared to $15 \%$ EDTA. We believe that if less concentrated solutions are as effective as higher concentrations, the first are preferable. Results showed that 1\% CDTA and 1\% EGTA solutions have a chelating action not very different from $15 \%$ EDTA. Thus, further research is necessary to determine if a minor increase in concentration of CDTA and EGTA would give equal or better results than $15 \%$ EDTA.

Çalt \& Serper (16) studied 17\% EGTA associated with $5 \%$ sodium hypochlorite and concluded that, at this concentration, EGTA promotes open dentinal tubuli, removes smear plug and is thus indicated as an alternative to EDTA for smear layer removal. There are many questions yet to be answered concerning EGTA and CDTA before these can be safely and regularly used in everyday practice. However, research slowly contributes to better understanding of their properties.

Figure 1 shows the similarities between Sealapex, $\mathrm{N}$-Rickert and Endofill sealers, independent of the chelating solutions applied. However, Sealer 26 had greater adhesion values when applied to dentin treated with EDTA or CDTA solutions than on dentin treated with EGTA or saline.

The presence of rosin can explain the results for $\mathrm{N}$-Rickert and Endofill sealers, because this component is responsible for adhesion by electrostatic bond of these sealers (7). Thus, the morphological changes produced by chelating solutions on dentin does not interfere with the adhesion of these sealers.

The chelating agent increased

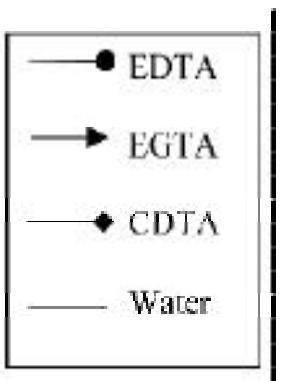

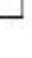

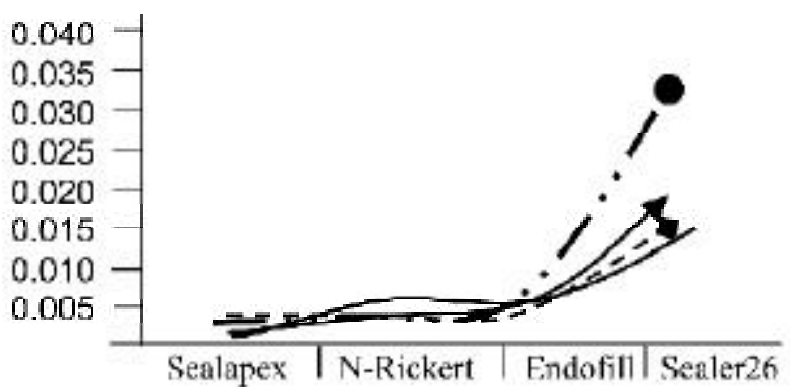

Figure 1. Tensile strength $(\mathrm{MPa})$ interaction between sealers and chelating solutions. adhesion values when compared to dentin without any treatment. EDTA, EGTA and CDTA removed smear layer, which permitted the penetration of epoxy-based sealer (Sealer 26) into the dentinal tubules. This favors a greater bonding between dentin and sealer, increasing the adhesion values compared to dentin without treatment. 
Sealapex presented the lowest adhesion values for the different treatments studied, in agreement with other studies (9). This can be explained by the high setting time, solubility and disintegration of this sealer (9) and low flow rate (17), thus impairing its ability to penetrate into dentinal tubules and promote a mechanical bond to dentin. Even with the removal of smear layer, which would allow a greater penetration into the dentinal tubules, this cement is easily displaced from the dentin due to its low cohesive structure.

Studies by Kennedy et al. (3) and Kouvas et al. (2), among others, showed that the smear layer acts as a physical barrier interfering with adhesion and penetration of the sealer, increasing apical leakage. According to Evans et al. (18), the presence or absence of smear layer has no significant effect on the apical seal. However, Saunders and Saunders (19) report that its removal can improve root canal sealing.

Regarding the physical-chemical properties of the root canal sealers, Sousa-Neto et al. (10) showed the need of removing smear layer for greater adhesion of epoxy-based sealers (Sealer 26) to dentin. The results obtained in the present study confirm a better apical seal with Sealer 26 when the smear layer is removed decreasing apical microleakage and contributing to a three-dimensional seal of the root canal system $(3,10)$.

According to Silva (20), many authors use the apical microleakage method to evaluate apical seal and also adhesion. In the literature, however, studies do not show a relation between these two variables, only suppositions. The results of the present study of the correlation and linear regression tests for 2 variables confirm no correlation between adhesion and apical microleakage.

Thus, it can be concluded that both adhesion and apical microleakage, when studied individually, can contribute to the physical-chemical studies of root canal sealers. This can lead to improvements in or creation of new root canal sealers.

\section{ACKNOWLEDGMENTS}

Research supported by a grant from $\mathrm{CNPq}$ (process no. 520078/99-3).

\section{RESUMO}

Sousa-Neto MD, Passarinho-Neto JG, Carvalho-Júnior JR, CruzFilho AM, Pécora JD, Saquy PC. Avaliação do efeito do EDTA,
EGTA e CDTA na adesividade e infiltração marginal de diferentes cimentos obturadores dos canais radiculares. Braz Dent J 2002;13(2):123-128

No presente estudo foi avaliado in vitro, o efeito da aplicação das soluções quelantes EDTA, EGTA, e CDTA sobre a dentina humana na adesividade e infiltração apical dos seguintes cimentos obturadores dos canais radiculares: Sealer 26, Sealapex, NRickert, e Endofill. Bem como observar se existe correlação matemática entre os testes de adesividade e infiltração marginal apical. Foram utilizados 80 dentes molares superiores e inferiores para o teste de adesividade, que tiveram suas coroas desgastadas na face oclusal até obter uma superfície de dentina plana onde o cimento era depositado com auxílio de um cilindro de alumínio $(10 \mathrm{~mm} \times 6 \mathrm{~mm}) . \mathrm{O}$ teste de adesividade foi realizado através da máquina universal de ensaio Instron 4444. O teste de infiltração marginal apical utilizou 160 caninos superiores, que após a instrumentação e obturação dos canais radiculares foram submetidos ao processo de diafanização para a visualização do nível de infiltração marginal apical. A penetração do nanquim na região apical foi medida através do microscópio de mensuração. Os dentes foram divididos em 4 grupos: grupo 1, água destilada; grupo 2, EDTA, grupo 3, EGTA; grupo 4, CDTA. Os resultados evidenciaram diferença estatística $(p<0.01)$ entre os cimentos e soluções testadas e não evidenciaram correlação matemática entre os testes de adesividade e infiltração marginal. $\mathrm{O}$ cimento Sealer 26 e a solução de EDTA apresentaram os melhores resultados para os testes de adesividade e infiltração marginal apical.

Unitermos: endodontia, propriedades físico-quimicas, cimentos obturadores dos canais radiculares.

\section{REFERENCES}

1. Cohen S, Burns RC. Pathways of the pulp. St Louis: Mosby; 1998.

2. Kouvas V, Liolios E, Vassiliadis L, Parissis-Messimeris S, Boutsioukis A. Influence of smear layer on depth of penetration of three endodontic sealers: an SEM study. Endod Dent Traumatol 1998;14:191-195.

3. Kennedy W, Walker WA, Gouch RW. Smear layer removal effects on apical leakage. J Endodon 1986;12:21-27.

4. Garberoglio R, Bedde C. Smear layer removal by root canal irrigants. A comparative scanning microscopic study. Oral Surg 1994;78:359-367.

5. Kabakov AY, Hilgemann DW. Modulation of $\mathrm{Na}^{+}, \mathrm{Ca}^{2+}$ exchange current by EGTA calcium buffering in giant cardiac membrane patches. Bioch Biophy Acta 1995;124:142-148.

6. Sánchez DJ, Gómez M, Domingo JL, Llobet JM. Relative efficacy of chelating agents on excretion and tissue distribution of manganese in mice. J Applied Toxicol 1995;15:285-288.

7. Sousa-Neto MD, Guimarães LF, Saquy PC, Pécora JD. Effect of different grades of gum rosins and hydrogenated resins on the solubility, disintegration, and dimensional alterations of Grossman cement. J Endodon 1999;25:477-480.

8. Ørstavik D. Physical properties of root canal sealers: measurement of flow, working time, and compressive strength. Int Endod J 1983;16:99-107.

9. Hyde DG. Physical properties of root canal sealers containing 
calcium hydroxide [Master's thesis]. Ann Arbor, MI: University of Michigan; 1986.

10. Sousa-Neto MD, Marchesan MA, Pécora JD, Brugnera-Junior A, Silva-Sousa YTC, Saquy PC. Effect of Er:YAG laser on adhesion of root canal sealers. J Endodon 2002;28:185-187.

11. Hasselgren G, Tronstad L. The use of transparent teeth in the teaching of preclinical endodontics. J Endodon 1975;8:25-34.

12. Østby NB. Chelation in root canal therapy. Ethylenediamine tetra-acetic acid for leasing and widening of root canals. Odont Tidskrift 1957;65:3-11.

13. Nikiforuk G, Sreebny L. Demineralization of hard tissues by organic chelating agents at neutral pH. J Dent Res 1953;32:859867.

14. Pécora JD, Guimarães LF, Savioli RN. Surface tension of several drugs used in endodontics. Braz Dent J 1991;2:123-127.

15. Johnson JD, Jiang Y, Flynn M. Modulation of $\mathrm{Ca}^{2+}$ transients and tension by intracellular EGTA in intact frog muscle fibers. Am J
Physiol 1997;272:1437-1444.

16. Çalt S, Serper A. Smear layer removal by EGTA. J Endodon 2000;26:459-461.

17. Fidel RAS, Sousa-Neto MD, Spanó JCE, Barbin LE, Pécora JD. Adhesion of calcium hydroxide-containing root canal sealers. Braz Dent J 1994;5:53-57.

18. Evans T, Simon JHS. Evaluation of the apical seal produced by infected thermoplasticized gutta-percha in the absence of smear layer and root canal sealer. J Endodon 1986;12:101-107.

19. Saunders WP, Saunders EM. The effect of smear layer upon the coronal leakage of gutta-percha root canal fillings and glass ionomer sealer. Int Endod J 1992;25:245-249.

20. Silva JRS. Avaliação do selamento marginal apical e de algumas propriedades físicas dos cimentos endodônticos Endobalsam e RRickert. [Master's thesis]. São Paulo: Universidade de São Paulo; $1985.93 \mathrm{p}$. 